Krenkel, einige Emendationen zu den Büchern Samuelis. 309

nymes Stück Za. 9-11 zwei weitere anonyme dadurch angefügt habe, dafs er ihnen aus 9,1 gebildete Ueberschriften gab. Ebenso nahe aber liegt die Annahme, dals er Za. 9-14 spaltete, veranlalst dadurch, dafs die Weissagung von c. 12 mit "ניִם "besonders einsetzt und sich durch ihren Inhalt vom Vorhergehenden merklich abhebt. Bei den Instanzen, welche für die Gleichartigkeit von Za. 9-11 und 12-14 sich uns ergaben und deren Gewicht bei einem Vergleich von Za. 9-14 mit Malachi noch steigt, dürfte man sich für das letztere zu entscheiden und

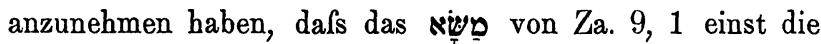
Ueberschrift des ganzen Buches 9-14 gewesen ist. So wäre schliefslich jener alte Redactor von der Schuld nicht frei zu sprechen, die Irrgänge der ein apologetisches Fündlein verwerthenden Kritik mit veranlalst zu haben.

\title{
Einige Emendationen za den Büchern Samuels.
}

\section{Von Max Krenkel.}

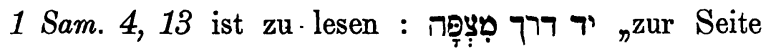
des Weges nach $M i z p a^{\text {(1) }}$ ), in dessen Nähe die für die Israeliten so unglückliche Schlacht vorfiel, denn nach 7, 12 errichtet Samuel den Denkstein zwischen Mizpa und השן an dem Orte, wo nach 4, 1 das israelitische Lager gestanden hatte.

16, 12. Statt des unerträglichen עם-יפה wird zu lesen

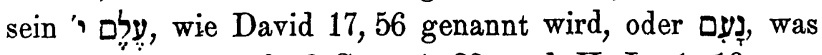
von Personen aucb 2 Sam. 1, 23 und H. L. 1, 16 vor-

1) Erst durch den Herausgeber erfahre ich, dals auch Wellhausen z. St. dies als Aussprache des Ketib annimmt. Meine Auffassung der Stelle datirt aus dem Jahre 1864, wo dieselbe den Beifall J. F ürst's fand. 
kommt. Im letzteren Falle wäre die Textverderbnifs durch die ungewöhnliche Scriptio defectiva veranlalst.

26, 8. Statt בחניח ובארץ ist jedenfalls mit veränderter Wortabtheilung zu lesen : בחניהi בארץ מנו in die Erde", zumal da V. 7 חנית vorhergeht.

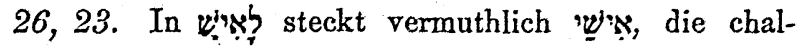
daisirende Form für 'שU!', die von den Abschreibern nicht verstanden wurde, aber noch 1 Chron: 2,13 vorkommt. Somit dürfte vielleicht zu lesen sein : לק: ב konnte, namentlich, wenn es abgekürzt wurde (' $\supset$ ), wegen des vorangehenden $ב$ (in Selbstbezeichnung Davids würde hier ganz am Platze sein.

$\mathrm{Zu} 2$ Sam. 22, 6 bemerkt Thenius : „Aug. Gesenius (opiniuncula de' 2 'שר שַאול 2 Sam. 22, 6 etc. 1747) wollte cohortes Sauli lesen". Noch ohne von dieser opiniuncula etwas zu wissen, war ich auf die Vermuthung gekommen,

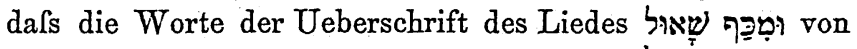
einem Leser herrühren, welcher in V. 6 las, dies aber als "Stricke Sauls" auffafste und hierbei an den 1 Sam. 19, $11 \mathrm{ff}$. berichteten Vorfall dachte, wo David

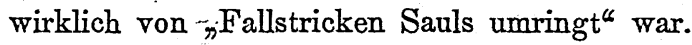

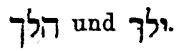 \\ Von Franz Prätorius.
}

Die meisten Grammatiker nehmen bekanntlich an, dafs zur Stammbildung und Flexion des hebr. Verbums für

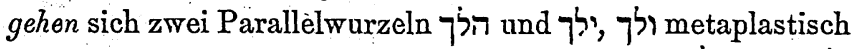

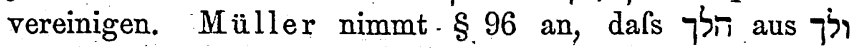
durch Uebergang von $w$ in $h$ entstanden sei. Aber eine alte Wurzel nicht. Daher haben andere Grammatiker versucht, diejenigen Formen, welche der angeblichen Wurzel ילך , ולך 